\title{
HARGA DIRI MAHASISWA YANG TERLAMBAT MENYELESAIKAN STUDI
}

\author{
Dede Rahmat Hidayat ${ }^{1}$, Siti Ramadhani ${ }^{2}$, Thalia Nursyifa ${ }^{3}$, \& \\ Yumna Afiyanti ${ }^{4}$ \\ e-mail: dederhidayat@unj.ac.id ${ }^{1}$, sitiramadhanyjmbk@gmail.com², \\ thalianursyifa15@gmail.com ${ }^{3}$, yumnafiyanti@gmail.com ${ }^{4}$ \\ Program Studi Bimbingan dan Konseling, Universitas Negeri Jakarta
} Jalan Rawamangun Muka Raya, RT.11/RW.14, Rawamangun, Kec. Pulo Gadung, Kota Jakarta Timur,

Daerah Khusus Ibukota Jakarta 13220

\begin{abstract}
Abstrak: Mahasiswa yang mengalami keterlambatan penyelesaian studi umumnya mengalami masalah akademik. Kondisi ini berdampak terhadap harga diri yang dimiliki oleh mahasiswa tersebut. Penelitian ini bertujuan untuk mengetahui tingkat harga diri mahasiswa yang terlambat menyelesaikan studi di wilayah Jabodetabek. Harga diri adalah penilaian seseorang terhadap dirinya, dalam penelitian ini diukur menggunakan Roserberg self-esteem scale. Metode penelitian yang digunakan adalah studi deskriptif kuantitatif dengan jumlah sampel sebanyak 71 orang, terdiri dari 49 mahasiswa perempuan dan 22 mahasiswa laki-laki. Hasil penelitian menunjukkan bahwa tingkat harga diri pada mahasiswa yang terlambat menyelesaikan studi di wilayah Jabodetabek berada pada kategori sedang. Berdasarkan kondisi tersebut penting bagi mahasiswa untuk merencanakan kuliah dengan tepat sehingga bisa lulus tepat waktu, karena berdampak pada aspek psikologis, termasuk harga diri. Harga diri akan berdampak kepada keyakinan diri untuk melaksanakan sesuatu.
\end{abstract}

Kata-kata Kunci: harga diri, keterlambatan penyelesaian studi, mahasiswa

\section{PRIDE OF STUDENTS WHO DELAYED THEIR STUDY}

\begin{abstract}
Students who experience delays in completing their study generally experience academic problems which impacting their pride. This study aims to determine the level of pride of students living in the Jabodetabek area who are late in completing their study. Pride is a person's assessment of her/himself which in this research is measured using the Rosenberg self-esteem scale. The research method used is a quantitative descriptive study with 71 participants, consisting of 49 female students and 22 male students. The results showed that the level of self-esteem of students living in the Jabodetabek area who were late in completing their study was in the medium category. Based on these conditions, students are suggested to plan their study appropriately so that they can graduate on time. Unplanned study will impact psychologically, including self-esteem which will have domino effects on other psychological aspect such as self-confidence.
\end{abstract}

Keywords: delayed in study completion, pride, students

\section{PENDAHULUAN}

Harga diri seseorang sangat dipengaruhi oleh situasi yang terkait dengan kehidupannya, berdasarkan penelitian Widodo (2013) yang meneliti harga diri dan interaksi sosial pada siswa SMK terungkap adanya hubungan yang positif juga signifikan antara harga diri dengan interaksi sosial hal 
ini disebabkan karena harga diri merupakan aspek yang menentukan keberhasilan seseorang dalam berinteraksi dengan lingkungan sosialnya. Sejalan dengan hal tersebut, Suci (2012) mengungkapkan bahwa terdapat hubungan positif antara pola asuh orangtua dengan harga diri, semakin baik pola asuh orangtua terhadap anak semakin tinggi pula harga diri anak. Selanjutnya, Hasiholan dan Sutejo (2015) menyatakan dukungan emosional keluarga memberikan efek pada harga diri remaja, di mana semakin banyak afeksi yang diberikan, maka remaja dapat termotivasi dalam mencapai tujuan hidupnya.

Menurut Sulistiyowati dalam Maiaweng (2011), kurangnya harga diri pada mahasiswa dapat mengakibatkan masalah akademik dan penampilan sosial, hal ini sangat berkaitan dengan pandangan bahwa semakin tinggi nilai akademik atau aktif di organisasi membuat harga diri mahasiswa menjadi lebih tinggi sedangkan bagi mahasiswa yang kesulitan untuk terus mempertahankan akademiknya membuat harga dirinya semakin menurun. Harga diri adalah kebutuhan dasar manusia, yang mempengaruhi motivasi, tingkah laku, kepuasan hidup dan kemantapan dalam menjalani kehidupan (Habsy, 2017). Tidak jarang bagi mahasiswa yang merasa jenuh dengan pendidikannya membuat tingkat harga dirinya ikut menurun, menurut Baron dan Byme dalam Mayasari dan Hadjam (2000), harga diri adalah penilaian terhadap diri sendiri yang dibuat individu dan dipengaruhi oleh karakteristik yang dimiliki orang lain yang menjadi pembanding. Bila mahasiswa melihat teman lainnya yang tetap aktif di organisasi kampus juga berprestasi dalam bidang akademik membuat harga diri mahasiswa lain menurun terutama bila ia tidak dapat lulus dengan tepat waktu.

Menurut Stuart, Sundeen dan Keliat dalam Hidayati (2016) seorang remaja dengan harga diri tinggi akan menunjukan perilaku menerima diri, percaya diri dan puas dengan kemampuannya sendiri, sedangkan remaja dengan harga diri rendah tidak akan menghargai kemampuan yang ia miliki dan tidak dapat menyesuaikan diri dengan lingkungannya. Mahasiswa yang membandingkan diri dengan temannya lain terutama yang dapat lulus tepat waktu tidak akan menghargai kemampuannya sendiri dan selalu meragukan dirinya sehingga hasilnya mahasiswa tersebut malah memperburuk akademiknya dan merasa memiliki harga diri yang lebih rendah dari teman-temannya yang lain.

Penelitian mengenai harga diri pada remaja dan dewasa akhir sudah banyak dilakukan. Salah satunya adalah penelitian Metsapelto, Zimmermann, Pakarinen,
Poikkeus dan Lerkkanen (2020) yang meneliti tingkat harga diri pada siswa berdasarkan kinerja akademis, kemudian juga penelitian Purnamasari dan Abdullah (2018) yang meneliti harga diri pada mahasiswa tingkat akhir berdasarkan kematangan kariernya, lalu penelitian Thalib (2016) meneliti harga diri pada mahasiswa FIP yang menunjukkan terdapat korelasi positif yang signifikan antara harga diri dan kemampuan bergaul mahasiswa. Pada penelitian Handayani, dan Helmi (2015) juga meneliti harga diri dan perfeksionisme pada mahasiswa yang menunjukkan individu dengna harga diri rendah cenderung memandang diri secara negatif.

Mahasiswa yang masa studinya lebih lama dari teman-temannya yang lain merasa tidak percaya diri dan tidak kompeten dalam menjalankan masa studinya karena ia menganggap dirinya kurang berusaha lebih baik dan bekerja keras untuk dapat menjalankan studinya dengan tepat waktu. Selain itu, faktor dari kesehatan dan juga ekonomi turut ambil bagian dalam isu ini. Mahasiswa yang memiliki isu ini dapat diakibatkan oleh faktor kesehatan dan faktor ekonomi. Mereka tidak dapat memaksimalkan masa studi yang normal seperti yang lain dan menjadi mengasingkan diri karena merasa malu dengan temantemannya.

Penelitian ini bertujuan untuk mengetahui tingkat harga diri mahasiswa yang terlambat menyelesaikan studi di Jabodetabek. Partisipan adalah mahasiswa tingkat akhir yang belum menyelesaikan studi dan mahasiswa yang mengulang mata kuliah sehingga menyebabkan terlambat menyelesaikan studi. Selain itu, penelitian ini juga bertujuan untuk mengetahui faktor dibalik keterlambatan kelulusan dari mahasiswa-mahasiswa tersebut.

Selfesteem atau yang biasa dikenal dengan harga diri memiliki definisi yang berbeda-beda dari berbagai ahli. Lyness berpendapat bahwa harga diri (self-esteem) adalah penilaian atau perkiraan seseorang terhadap dirinya sendiri. Pengenalan terhadap harga diri yang dimiliki seseorang adalah penting baginya karena akan mempengaruhi cara ia menjalani hidupnya, penerimaan terhadap dirinya, bagaimana ia menjalani relasi dengan orang lain (Maiaweng P. , 2011).

Pada umumnya para ahli mendefinisikan harga diri adalah konstruk yang penting dalam kehidupan sehari-hari dan berperan dalam menentukan tingkah laku seseorang yang meliputi penilaian, perasaan atau pandangan individu terhadap dirinya atau hal-hal yang berkaitan dengan dirinya yang diekspresikan pada dimensi positif yaitu menghargai kelebihan diri serta menerima kekurangan yang ada dan dimensi 
negatif yaitu tidak puas dengan kondisi diri, tidak menghargai kelebihan diri serta melihat diri sebagai sesuatu yang selalu kurang. Individu cenderung mengevaluasi diri berdasarkan perbandingan dengan orang lain. Individu cenderung mengevaluasi diri berdasarkan perbandingan dengan orang lain. Harga diri merupakan evaluasi diri individu yang mengekspresikan perilaku setuju atau tidak setuju dan mengindikasikan tingkat individu dalam meyakini dirinya mampu, berarti, berhasil dan berharga (Conger dalam Yusuf \& Ropyanto, 2012).

Berbeda dengan Shrout dan Weigel (2020), bahwa harga diri adalah rasa stabil akan rasa suka pada diri sendiri, harga diri, dan penerimaan diri. Individu yang mempunyai tingkat harga diri yang lebih baik dalam mengatur diri sendiri cenderung melihat ancaman bukan peristiwa yang menimbulkan tekanan, biasanya mereka lebih percaya diri dan mampu menangani stressnya.

Berdasarkan beberapa definisi diatas dapat disimpulkan bahwa harga diri adalah bagaimana seseorang memandang dirinya sendiri. Harga diri sangat berperan dalam mempengaruhi individu untuk mengartikan dan mengatur setiap peristiwa dan pengalaman yang mendorong lahirnya gagasangagasan, rencana-rencana serta tingkah laku yang sesuai.

Coopersmith dalam Ekasari \& Andriyani (2013) menyebutkan bahwa terdapat empat aspek dalam self-esteem individu. Aspek-aspek tersebut antara lain power, significance, virtue, dan competence. Kemampuan seseorang dalam mengatur perilaku dan mendapat pengakuan dari orang lain merupakan kekuatan yang dimiliki individu untuk mencapai penghargaan juga penghormatan.

Selain kekuatan dalam diri individu, sikap orang lain yang memberikan kepedulian juga tertarik dengan diri individu membuat individu merasakan keberartian dan nyaman di lingkungannya. Pentingnya menerapkan kebajikan pada diri individu membuatnya dipandang baik dan menjauhi melanggar peraturan dapat memberikan dampak positif terhadap harga diri individu itu sendiri. Individu yang mengetahui tugas perkembangannya dan berprestasi, dalam pencapaiannya dapat dikatakan mampu mengatasi tugas-tugas tersebut karena memiliki kemampuan atau kompetensi yang baik. Kompetensi juga merupakan aspek yang penting dalam harga diri individu.

Coopersmith menjelaskan terdapat faktor yang dapat meningkatkan atau menurunkan penghargaan seseorang terhadap dirinya sendiri yaitu ketika seseorang dapat penerimaan atau penghargaan atas dirinya, ketika ia memiliki popularitas atau mendapat jabatan kepemimpinan, kemudian faktor dari keluarga juga orangtua dan faktor dari asertivitas ataupun kecemasan yang dimiliki oleh seseorang tersebut (Ekasari \& Andriyani, 2013).

Menurut Branden siswa dengan harga diri yang tinggi memiliki karakteristik yaitu gemar mengambil risiko yang positif seperti mengetahui ketika akan gagal tetapi juga mengetahui saat ia akan berhasil. Selain itu, siswa juga berani mengambil risiko negatif seperti menghargai diri sendiri juga menghindari situasi yang berbahaya. Siswa juga menolak tekanan dari teman sebaya yang dirasa negatif dan cenderung untuk pergi bersama dengan banyak teman atau banyak orang. Seorang siswa yang memiliki harga diri tinggi dan karakteristik positif yang cukup banyak seperti kuat dan dapat mengatasi perubahan juga tantangan hidup, ulet dan dapat bangkit kembali ketika memiliki masalah, menetapkan tujuan dan berusaha untuk meraihnya, ia juga merasa bebas untuk berkreativitas dan selalu memiliki sikap positif pada kehidupannya (Ekasari \& Andriyani, 2013).

Penelitian mengenai harga diri terutama kepada mahasiswa tingkat akhir memiliki relevansi dengan beberapa penelitian yang telah dilakukan sebelumnya. Pada penelitian yang dilakukan oleh Purnasari dan Abdullah (2018) menunjukkan adanya hubungan positif antara harga diri dengan kematangan karier pada mahasiswa S1 tingkat akhir. Penelitian ini memperlihatkan bahwa harga diri tersusun dari kekuatan individu (power). Kekuatan individu adalah kemampuan untuk mempengaruhi orang lain, serta mengendalikan orang lain, selain mengontrol atau mengendalikan dirinya sendiri. Bila seorang mahasiswa S1 tingkat akhir memiliki kekuatan individu yang tinggi, maka mahasiswa tersebut akan mampu mengontrol diri sendiri dan orang lain dengan baik, dapat mempersiapkan kariernya dengan baik. Kemudian, kompetensi juga merupakan salah satu aspek dari harga diri di mana kompetensi merupakan kemampuan untuk mendapatkan prestasi yang baik, yang menyesuaikan dengan umur atau tahapan usia. Menurut phares kemampuan seseorang untuk percaya bahwa kesuksesan dan kegagalan yang telah terjadi sangat dipengaruhi oleh kemampuan yang dimiliki. Brandent (2005) menjelaskan harga diri ialah penilaian personal individu pada kompetensi dirinya, bahwa ia mampu menghadapi tantangan hidup sehingga layak untuk mendapat kebahagiaan. Mahasiswa merasa bahwa prestasi akademik dan soft skill yang dimiliki adalah hal utama yang diukur untuk menilai 
kompetensinya dalam menunjang kariernya kelak, maka individu tersebut akan melakukan usaha yang maksimal dengan berfikir realistis dengan prestasi yang dicapai dan dapat mencapai prestasi akademik yang tinggi dan memiliki soft skill yang tinggi serta konsisten dalam pencapaian prestasinya. Coopersmith (1967) menjelaskan bahwa seseorang yang taat terhadap nilai moral, etika dan agama dianggap memiliki sikap yang positif dan akhirnya membuat penilaian positif terhadap diri yang artinya seseorang telah mengembangkan harga diri yang positif pada diri sendiri. Mahasiswa yang mentaati peraturan yang ada dalam pemenuhan syarat penerimaan kerja serta dapat mempersiapkan diri dalam penentuan kariernya dan konsisten dalam hal tersebut, ia akan semakin menjadi inspirasi yang baik bagi teman-temannya. Tingkat harga diri yang tinggi membuat kematangan karier pada mahasiswa S1 tingkat akhir menjadi tinggi pula karena aspek harga diri seperti kekuatan individu, kompetensi dan kemampuan untuk memberi contoh dapat meningkatkan harga diri pada mahasiswa tingkat akhir.

Kemudian pada penelitian Kharsah (2016) yang melakukan penelitian mengenai korelasi antara harga diri, komitmen universitas dan juga kinerja akademik pada mahasiswa tingkat akhir juga menjelaskan bahwa individu yang memiliki harga diri tinggi umumnya suka mengambil tujuan yang lebih menantang daripada individu dengan harga diri rendah. Beberapa peneliti berpendapat bahwa siswa yang berprestasi lebih tinggi di universitas memiliki harga diri yang positif, sementara yang lain berpendapat bahwa harga diri yang positif adalah prasyarat yang diperlukan dalam kinerja akademik observasi pada korelasi antara harga diri dan kinerja akademik tercatat secara positif yang berarti siswa yang memiliki harga diri tinggi akan mendapatkan kinerja tinggi, sedangkan mereka yang memiliki harga diri rendah, akan mendapatkan kinerja akademik yang rendah.

Penelitian lainnya oleh Maheswari dan Maheswari (2016) yang melakukan penelitian mengenai harga diri pada mahasiswa laki-laki tingkat akhir menjelaskan bahwa harga diri adalah persepsi dari perasaan, pikiran mengenai diri sendiri seperti bagaimana diri terlihat oleh orang lain, dirasakan, dan juga berperilaku. Pada penelitian ini menunjukkan bahwa sebesar 52,5\% dari keseluruhan responden memiliki harga diri rendah dan 47,5 persen responden memiliki harga diri tinggi. Terdapat perbedaan yang signifikan di antara usia responden dan harga diri yang menunjukkan bahwa seiring bertambahnya usia, harga diri juga meningkat.
Pada penelitian Hidayati (2016) yang melakukan penelitian mengenai hubungan harga diri dan konformitas teman sebaya dengan kenalakan remaja menjelaskan bahwa remaja memiliki harga diri tinggi untuk menunjukkan prilaku menerima dirinya apa adanya, percaya diri, puas dengan karakternya dan kemampuan diri dan individu yang memiliki harga diri rendah, akan menunjukkan penghargaan buruk terhadap dirinya sehingga tidak mampu menyesuaikan diri dengan lingkungan. Metode penelitian ini menggunakan metode deskriptif. menggunakan tiga variable yang dihubungkan yaitu kenalakan remaja sebagai ariable terikat, harga diri sebagai variable bebas 1 dan konformitas teman sebaya adalah variable bebas 2. Sampel penelitian berjumlah 159 siswa SMA di Kalimantan Barat. Hipotetis menyatakan bahwa terdapat hubungan antara harga diri, konformitas teman sebaya dengan kenakalan remaja. Hasilnya menunjukkan terdapat perbedaan yang signifikan. Besarnya pengaruh yang diberikan oleh variabel harga diri, konformitas teman sebaya terhadap kenakalan remaja yaitu sebesar 73,4\% sedangkan sisanya 26,6\% dipengaruhi oleh variabel yang lainnya.

\section{METODE PENELITIAN}

Penelitian ini bertujuan untuk mengetahui bagaimana gambaran tingkat harga diri pada mahasiswa di Jabodetabek yang terlambat menyelesaikan studi. Penelitian dilakukan pada bulan Mei sampai bulan Juni tahun 2020. Variabel penelitian ini hanya satu variabel atau variabel tunggal yaitu Harga Diri. Menurut Nawawi dan Hadari (1992) variable tunggal adalah variabel yang hanya mengungkapkan untuk dideskripsikan unsur atau faktor-faktor di dalam setiap gejala yang termasuk variabel tersebut, penelitian seperti ini disebut variabel tunggal.

Penelitian ini merupakan penelitian kuantitatif dengan menggunakan metode deskriptif. Penelitian bertujuan untuk memberikan uraian mengenai suatu permasalahan sosial yang akan diteliti dengan mendeskripsikan suatu permasalahan berdasarkan pada indikator-indikator yang dijadikan dasar. Metode ini dilakukan untuk menggambarkan variabel harga diri pada mahasiswa di Jabodetabek yang terlambat menyelesaikan studi.

\section{Populasi, Sampel dan Sampling}

Populasi pada penelitian ini adalah mahasiswa yang terdiri dari beberapa perguruan tinggi di Jabodetabek yang terlambat menyelesaikan studi. Teknik sampling yang digunakan dalam penelitian 
ini adalah snowball sampling. Pengumpulan data secara online ini juga agar lebih efektif untuk mencapai partisipan yang letaknya jauh dari kami. Melalui instrumen yang disebarkan secara online mempermudah kelompok untuk mendapatkan pasrtisipan. Setelah berusaha menyebarkan instrumen secara online melalui social media selama dua minggu, peneliti berhasil mendapatkan jumlah partisipan sebanyak 71 orang yang terdiri dari perempuan 49 orang (69\%) dan laki-laki 22 orang (31\%).

\section{Teknik Pengumpulan Data}

Metode pengumpulan data yang digunakan dalam penelitian ini adalah menggunakan Rosenberg Self-Esteem Scale (RSE) yang dikembangkan oleh Morris Rosenberg (1965). Pada awalnya skala ini dibuat untuk mengukur harga diri siswa menengah, namun skala ini berkembang dan digunakan untuk berbagai kelompok termasuk orang dewasa. RSE menggunakan Skala Likert yang memiliki dua bentuk pernyataan, yaitu pernyataan positif (favorable) dan pernyataan negatif (unfavorable). RSE memiliki 10 item pernyataan yang digunakan untuk mengukur harga diri yang terdiri dari 5 pernyataan positif dan 5 pernyataan negatif. Terdapat 4 pilihan jawaban dalam RSE, yaitu: 1 = sangat tidak setuju sampai dengan 4 = sangat setuju (Greenberger, Chen, Dmitrieva, \& Farruggia, 2003).

Tabel 1.

Kisi-Kisi Rosenberg Self-Esteem Scale (RSE)

\begin{tabular}{llcc}
\hline No. & \multicolumn{1}{c}{ Indikator/Dimensi } & No. Item & Skala \\
\hline 1. $\begin{array}{l}\text { Penghargaan Diri Positif } \\
\text { (positive self worth) }\end{array}$ & 1,3 & $1-4$ \\
$\begin{array}{l}\text { Citra Diri Positif (positive } \\
\text { 2.lfimage) }\end{array}$ & $4,7,10$ & $1-4$ \\
$\begin{array}{l}\text { Penghinaan Diri (self } \\
\text { derogation) }\end{array}$ & $5,6,8$ & $1-4$ \\
$\begin{array}{l}\text { Citra Diri Negatif (negative } \\
\text { selfimage) }\end{array}$ & 2,9 & $1-4$ \\
\hline
\end{tabular}

\section{Uji Instrumen}

1. Validitas

Uji validitas instrument dilakukan dengan mengitung korelasi item-total, dengan menggunakan rumus korelasi Pearson diperoleh skor korelasi dalam rentang antara $\mathrm{r}=057$ sampai dengan $r=0,88$.

Rumus korelasi product moment Pearson

$$
r_{x y}=\frac{n \sum X Y-\left(\sum X\right)\left(\sum Y\right)}{\sqrt{\left\{\sum X^{2}-\left(\sum X\right)^{2}\right\}\left\{n \sum Y^{2}-\left(\sum Y\right)^{2}\right\}}}
$$

2. Reliabilitas

Uji reliabilitas menggunakan Cronbach Alpha yang dilakukan menunjukan hasil korelasi dari 0.85 dan 0,88. Hal ini menunjukan stabilitas yang baik.

\section{Teknik Analisis Data}

Analisis statistika yang digunakan pada penelitian ini adalah statistik deskriptif. Berupa penghitungan Rerata (Mean) dan simpangan baku (standar deviasi)

Rumus penghitungan Rerata (mean)

Keterangan:

$$
\bar{x}=\sum_{i=1}^{n} \frac{x i}{n}
$$

$\bar{\chi}=$ rata-rata sampel

$\boldsymbol{x} \boldsymbol{i}=$ nilai observasi ke- 1

$n$ = jumlah sampel

Rumus simpangan baku (Standar deviasi)

Keterangan:

$$
s=\sqrt{\frac{n \sum_{i=1}^{n} x_{1}^{2}-\left(\sum_{i=1}^{n} x_{1}\right)^{2}}{n(n-1)}}
$$

$s^{2}=$ varian

$s \quad=$ standar deviasi (simpangan baku)

$x i=$ nilai $x$ ke- $i$

$\bar{\chi}=$ rata-rata

$n=$ ukuran sampel

\section{HASIL DAN PEMBAHASAN}

\section{Hasil Analisis deskriptif}

Tabel 2.

Hasil Data Keseluruhan

\begin{tabular}{ccccc}
\hline $\begin{array}{c}\text { Total } \\
\text { Responden }\end{array}$ & $\begin{array}{c}\text { Skor } \\
\text { Rata-rata }\end{array}$ & $\begin{array}{c}\text { Skor } \\
\text { Max }\end{array}$ & $\begin{array}{c}\text { Skor } \\
\text { Min }\end{array}$ & $\begin{array}{c}\text { Standar } \\
\text { Deviasi }\end{array}$ \\
\hline 71 & 27,46 & 38 & 16 & 5,09 \\
\hline
\end{tabular}

Berdasarkan tabel di atas, dapat dilihat bahwa pada penelitian ini total responden yang dilibatkan sebanyak 71 partisipan. Skor rata-rata yang didapatkan adalah 27,46 dengan standar deviasi 5,09. Skor tertinggi pada penelitian ini adalah 38 dan terendah adalah 16 .

Tabel 3.

Skor Rerata Setiap Butir

\begin{tabular}{ccc}
\hline No. Item & Rerata & Standar Deviasi \\
\hline 1. & 2,78 & 0,73 \\
2. & 2,49 & 0,92 \\
3. & 2,94 & 0,75
\end{tabular}




\begin{tabular}{ccc}
\hline No. Item & Rerata & Standar Deviasi \\
\hline 4. & 3,04 & 0,66 \\
5. & 2,76 & 0,99 \\
6. & 2,66 & 0,92 \\
7. & 3,11 & 0,68 \\
8. & 1,69 & 0,76 \\
9. & 2,74 & 0,85 \\
10. & 3,22 & 0,72 \\
\hline
\end{tabular}

Sumber : Hasil Penelitian

Berdasarkan tabel di atas, dapat dilihat bahwa pada penelitian ini medapatkan hasil mean dan standar deviasi pada setiap item, yaitu nomer item 1 memiliki mean 2,78 dan standar deviasi 0,73, nomer item 2 memiliki mean 2,49 dan standar deviasi 0,92, nomer item 3 memiliki mean 2,94 dan standar deviasi 0,75, nomer item 4 memiliki mean 3,04 dan standar deviasi 0,66, nomer item 5 memiliki mean 2,76 dan standar deviasi 0,99, nomer item 6 memiliki mean 2,66 dan standar deviasi 0,92, nomer item 7 memiliki mean 3,11 dan standar deviasi 0,68, nomer item 8 memiliki mean 1,69 dan standar deviasi 0,76, nomer item 9 memiliki mean 2,74 dan standar deviasi 0,85, nomer item 10 memiliki mean 3,22 dan standar deviasi 0,72.

Berdasarkan hasil pengolahan dan penelitian ini dapat dikategorisasi tingkat harga diri mahasiswa yang terlambat menyelesaikan studi sebagai berikut :

Tabel 4.

Sebaran persentase harga diri berdasarkan kategori

\begin{tabular}{lcc}
\hline \multicolumn{1}{c}{ Kategori } & Frekuensi & \% \\
\hline Tinggi & 11 & $15,49 \%$ \\
Sedang & 50 & $70,42 \%$ \\
Rendah & 10 & $14,09 \%$ \\
\hline & 71 & $100,00 \%$ \\
\hline
\end{tabular}

Sumber : Hasil Penelian

Hasil Penelitian ini terbagi pada 3 kategori yaitu tinggi, sedang dan rendah dan berdasarkan hal tersebut menunjukkan bahwa tingkat harga diri pada mahasiswa yang terlambat menyelesaikan studi seJabodetabek berada pada kategori sedang.

\section{Diskusi}

Mahasiswa yang memiliki tingkat harga diri yang tinggi merupakan mahasiswa yang dapat menghargai dirinya secara positif dan juga memiliki citra diri yang positif pada diri sendiri. Harga diri adalah rasa stabil akan rasa suka pada diri sendiri, harga diri, dan penerimaan diri (Shrout dan Weigel. 2020). Oleh sebab itu mahasiswa yang memiliki tingkat harga diri tinggi walaupun ia memiliki keterlambatan atau terlambat menyelesaikan studi dapat tetap menjalankan masa studinya dan tidak merasa minder karena ia yakin bahwa ia bisa menyelesaikan studinya dengan baik dan percaya pada dirinya bahwa ia mampu.

Menurut Branden dalam Ekasari dan Andriyani (2013) siswa dengan harga diri yang tinggi memiliki karakteristik yaitu gemar mengambil risiko yang positif seperti mengetahui ketika akan gagal tetapi juga mengetahui saat ia akan berhasil. Selain itu, siswa juga berani mengambil risiko negatif seperti menghargai diri sendiri juga menghindari situasi yang berbahaya. Siswa juga menolak tekanan dari teman sebaya yang dirasa negatif dan cenderung untuk pergi bersama dengan banyak teman atau banyak orang. Seorang siswa yang memiliki harga diri tinggi memiliki karakteristik positif yang cukup banyak seperti kuat dan dapat mengatasi perubahan juga tantangan hidup, ulet dan dapat bangkut kembali ketika memiliki masalah, menetapkan tujuan dan berusaha untuk meraihnya, ia juga merasa bebas untuk berkreativitas dan selalu memiiliki sikap positif pada kehidupannya. Berdasarkan karakteristikkarakteristik tersebut mahasiswa yang terlambat menyelesaikan studi dengan tingkat Harga Diri yang tinggi tetap memiliki karakteristik tersebut dan dengan karakteristik tersebut mahasiswa tetap dapat menjalankan akademiknya dengan baik walaupun lebih lama dari teman-temannya yang lain. Mahasiswa dengan tingkat harga diri tinggi akan mampu bangkit dari masalah yang ia alami dan juga dapat mengatasi perubahan di dalam hidupnya di mana pada mahasiswa yang memiliki tingkat harga diri rendah kesulitan untuk dapat memiliki karakteristikkarakteristik positif seperti mahasiswa yang memiliki tingkat harga diri tinggi.

Mahasiswa dengan tingkat harga diri rendah merupakan mahasiswa yang melakukan dan merasakan penghinaan pada diri dan juga memiliki citra diri yang negatif pada diri sendiri oleh sebab itu ia kesulitan untuk dapat bangkit dari masalah yang pernah ia alami, menghadapi rintangan hidup dan juga untuk melawan kegagalan yang pernah rasakan. Mahasiswa yang terlambat menyelesaikan studi dan memiliki tingkat harga diri yang rendah kemungkinan tersendat dengan masalah yang ia miliki terutama pada masalah akademiknya karena ia tidak dapat bersikat positif atas kehidupannya dan bangkit dari keterpurukannya.

\section{Keterbatasan Penelitian}

Penelitian ini telah dilaksanakan sesuai dengan 
prosedur penelitian. Adapun keterbatasan yang dihadapi peneliti ketika meneliti penelitian ini yaitu:

1. Kesulitan dalam mencari sumber literasi yang sesuai dan berkaitan antara isu dengan variabel tunggal

2. Kesulitan dalam mendapatkan responden yang sesuai dengan kriteria yang diinginkan dan bersedia untuk menjadi responden

3. Angket yang sudah diisi tidak menjamin terjawab dengan sungguh-sungguh atau sesuai dengan keadaan individu yang sebenarnya

4. Bila responden tidak memahami salah satu pertanyaan di dalam angket sulit untuk dapat memberikan petunjuk atau menjelaskannya karena penelitian dilakukan secara online

\section{PENUTUP}

\section{Simpulan}

Tingkat harga diri pada mahasiswa yang terlambat menyelesaikan studi di wilayah Jabodetabek memiliki skor rata-rata 27,46 dari total skor ideal 40. Hasil Penelitian ini terbagi pada 3 kategori yaitu tinggi, sedang dan rendah dan berdasarkan hal tersebut menunjukkan bahwa tingkat harga diri pada mahasiswa yang terlambat menyelesaikan studi di wilayah Jabodetabek berada pada kategori sedang.

Mahasiswa yang terlambat menyelesaikan studi dengan tingkat harga diri yang tinggi tetap memiliki karakteristik tersebut dan dengan karakteristik tersebut mahasiswa tetap dapat menjalankan akademiknya dengan baik walaupun lebih lama dari temantemannya yang lain. Mahasiswa dengan tingkat harga diri tinggi akan mampu bangkit dari masalah yang ia alami dan juga dapat mengatasi perubahan di dalam hidupnya di mana pada mahasiswa yang memiliki tingkat harga diri rendah kesulitan untuk dapat memiliki karakteristik-karakteristik positif seperti mahasiswa yang memiliki tingkat harga diri tinggi.

Mahasiswa dengan tingkat harga diri rendah merupakan mahasiswa yang melakukan dan merasakan penghinaan pada diri dan juga memiliki citra diri yang negatif pada diri sendiri oleh sebab itu ia kesulitan untuk dapat bangkit dari masalah yang pernah ia alami, menghadapi rintangan hidup dan juga untuk melawan kegagalan yang pernah rasakan. Mahasiswa yang terlambat menyelesaikan studi dan memiliki tingkat harga diri yang rendah kemungkinan tersendat dengan masalah yang ia miliki terutama pada masalah akademiknya karena ia tidak dapat bersikatp positif atas kehidupannya dan bangkit dari keterpurukannya.

\section{DAFTAR PUSTAKA}

Ekasari, A., \& Andriyani, Z. (2013). Pengaruh Peer Group Support dan Self-Esteem Terhadap Resilence pada Siswa SMAN Tambun Utara BekasiI. SOUL: Jurnal Pemikiran dan Penelitian Psikologi, 6(1), 1-20.

Branden, N. (2007). 6 Pilar Penghargaan Diri. Semarang: Dahara Prize.

Coopersmith, S. (1987). Self-esteem inventories (SEI): Self-esteem inventories. Palo Alto: Consulting Psychologist Press.

Greenberger, E., Chen, C., Dmitrieva, J., \& Farruggia, S. P. (2003). Item-wording and the dimensionality of the Rosenberg Self-Esteem Scale: Do they matter?. Personality and individual differences, 35(6), 1241-1254.

Habsy, B. A. (2017). Model konseling kelompok cognitive behavior untuk meningkatkan self esteem siswa SMK. Perspektif Ilmu Pendidikan, 31(1), 21-35, DOI: https://doi.org/10.21009/ PIP.311.4.

Handayani, M. M., Ratnawati, S., \& Helmi, A. F. (2015). Efektifitas pelatihan pengenalan diri terhadap peningkatan penerimaan diri dan harga diri. Jurnal Psikologi, 25(2), 47-55, DOI: 10.22146/ jpsi.7504.

Hasiolan, M. I. S., \& Sutejo, S. (2015). Efek Dukungan Emosional Keluarga pada Harga Diri Remaja: Pilot Study. Jurnal Keperawatan Indonesia, 18(2), 67-71, DOI: 10.7454/jki.v18i2.400.

Hidayati, N. W. (2016). Hubungan harga diri dan konformitas teman sebaya dengan kenakalan remaja. Jurnal Penelitian Pendidikan Indonesia, 1(2).

Kharsah, W.S., \& Fatmawati, L. (2016). The correlation between levels of self-esteem, university commitment and academic performance among undergraduate students. In Proceedings of the National Conference for Postgraduate Research, Universiti Malaysia Pahang, Pekan, September 24, 25, 200-205).

Maheswari, R., \& Maheswari, K. (2016). A study on self-esteem among college students. Journal of Humanities and Social Science, 21(10), 8-10, DOI: 10.9790/0837-2110080810.

Maiaweng, P. C. (2011). Korelasi Harga Diri Dan Penerimaan Sosial Terhadap Kepribadian Yang Sehat pada Mahasiswa STT Jaffray Makassar. Jurnal Jaffray, 9(1), 1-24, DOI: http://dx.doi. org/10.25278/jj71.v9i1.86.

Mayasari, F., \& Hadjam, M. N. R. (2000). Perilaku 
seksual remaja dalam berpacaran ditinjau dari harga diri berdasarkan jenis kelamin. Jurnal Psikologi, 27(2), 120-127, DOI: 10.22146/ jpsi.7004.

Metsäpelto, R. L., Zimmermann, F., Pakarinen, E., Poikkeus, A. M., \& Lerkkanen, M. K. (2020). School grades as predictors of self-esteem and changes in internalizing problems: A longitudinal study from fourth through seventh grade. Learning and Individual Differences, 77, DOI: http://doi.org/10.1016/j.lindif.2019.101807.

Nawawi, H., \& Hadari, M. (1992). Instrumen Penelitian Bidang Sosial. Yogyakarta: Gadjah Mada University Press.

Purnasari, K. D., \& Abdullah, S. M. (2018). HARGA DIRI DAN KEMATANGAN KARIER PADA MAHASISWA TINGKAT AKHIR. Insight: Jurnal Ilmiah Psikologi, 20(1), 51-68, DOI: https:/ / doi.org/10.26486/psikologi.v20i1.633.

Rosenberg, M. (1965). Society and the adolescent selfimage. Princeton, NJ: Princeton University Press.
Salamiah, N. S., \& Suci, D. H. (2011). Hubungan Intelegensi Dan Pola Asuh Orangtua Demokratis Dengan Harga Diri Siswa. Analitika, 3(2), 99114, DOI: https://doi.org/10.31289/analitika. v3i2.746.

Shrout, M. R., \& Weigel, D. J. (2020). Coping with infidelity: The moderating role of self-esteem. Personality and Individual Differences, 154, DOI: https://doi.org/10.1016/j.paid.2019.109631.

Thalib, S. B. (2016). Hubungan percaya diri dan harga diri dengan kemampuan bergaul mahasiswa. Jurnal Ilmu Pendidikan, 6(3), 247-256, DOI: http://dx.doi.org/10.17977/jip.v6i3.776.

Widodo, A. S. (2013). Harga diri dan interaksi sosial ditinjau dari status sosial ekonomi orang tua. Persona: Jurnal Psikologi Indonesia, 2(2), DOI: https://doi.org/10.30996/persona.v2i2.100.

Yusuf, L., \& Ropyanto, C. B. (2012). Harga Diri pada Remaja Menengah Putri di SMA Negri 15 Kota Semarang. Jurnal Keperawatan Diponegoro, 1(1), 225-230. 